\title{
Taxonomic confusion around the Peach Twig Borer, Anarsia lineatella Zeller, 1839, with description of a new species (Lepidoptera, Gelechiidae)
}

\author{
Keld Gregersen $^{1}$, Ole Karsholt ${ }^{2}$ \\ 1 Fru Ingesvej 13,DK-4180,Denmark; Keld_gregersen@stofanet.dk \\ 2 Zoological Museum, Natural History Museum of Denmark, Universitetsparken 15, DK-2100 Copenhagen, Denmark; \\ okarsholt@snm.ku.dk
}

http://zoobank.org/B06525D1-90F4-469F-B156-F33933FD7889

Received 7 January 2017; accepted 31 January 2017; published: 23 March 2017

Subject Editor: Lauri Kaila.

\begin{abstract}
A new species of Gelechiidae is described as Anarsia innoxiella sp. n., based on differences in morphology and biology. It is closely related to and has hitherto been confused with the Peach Twig Borer, Anarsia lineatella Zeller, 1839. Whereas larvae of the latter feed on - and are known to be a pest of - Prunus species (Rosaceae), the larva of $A$. innoxiella feeds on Acer species (Sapindaceae). All known synonyms of $A$. lineatella are discussed in detail, including Anarsia lineatella subsp. heratella Amsel, 1967, from Afghanistan and A. lineatella subsp. tauricella Amsel, 1967, from Turkey. Our study has shown no evidence for changing the present taxonomic status of these two taxa. We discuss also the status of the genus Ananarsia Amsel, 1957. The new species $A$. innoxiella is widely distributed in Europe and is often found in the same areas as A. lineatella, but the latter species does not occur naturally in northern Europe. A. innoxiella seems not to be of economic importance. We propose, in line with the provisions of Article 23.9 of the International Code of Zoological Nomenclature, suppression of the priority of Tinea pullatella Hübner, 1796, nomen oblitum, over Anarsia lineatella Zeller, 1839, nomen protectum. An appendix with references on the prevailing use of the latter species is included.
\end{abstract}

\section{Introduction}

The peach twig borer, Anarsia lineatella, was described in 1839 by Zeller and has since been known as a pest of stone fruits of the genus Prunus (Rosaceae). It has for several years been assumed among specialists studying the family Gelechiidae that Anarsia lineatella s.l. includes hidden diversity. In Europe there are at least two widely distributed distinct species: A. lineatella and a closely related species feeding on Acer (Sapindaceae) which is described in the present paper as A. innoxiella sp. n.

When A. lineatella was first reported from Denmark (Wolff 1965), the Danish State Plant Pathology Institute seriously considered removing all cultivated Prunus trees in the vicinity of the place it was found (Th. Thygesen, pers. comm.). The proposal was rejected for practical reasons, which was fortunate as the species reported by Wolff was misidentified, its true identity being $A$. innoxiella, the larva of which feeds on Acer not Prunus. 


\section{Material and methods}

Data from holotypes are cited exactly as on the labels of the specimens (Fig. 1), whereas other material is organised in a standardized way rather than verbatim, viz. alphabetic after country and province; material from the same province is listed chronologically. Abbreviations for Danish faunistic provinces follow Enghoff and Nielsen (1977).

Genitalia preparation mostly follows the technique described by Huemer and Karsholt (2010). Male genitalia were 'unrolled'. In some cases female genitalia were left inside the abdomen to avoid distortion of characters. Photographs of adults were taken using Leica Application Suit MZ 16A, and ZERENE HELICON Stacker program was used for stacking subsequent images. Photographs of genitalia slides were taken using an Olympus SZX16 microscope with motorized focus drive attached to an Olympus E520 digital camera. All images have been edited in ADOBE Photoshop. Line-drawings have been performed by KG and edited in ADOBE Photoshop. Plates and figures are not to exact scale.

Description of genital morphology follows Kristensen (2003a, 2003b), with additions from Ponomarenko (2005) and a few other modifications.

The present study is based on material from the following collections:

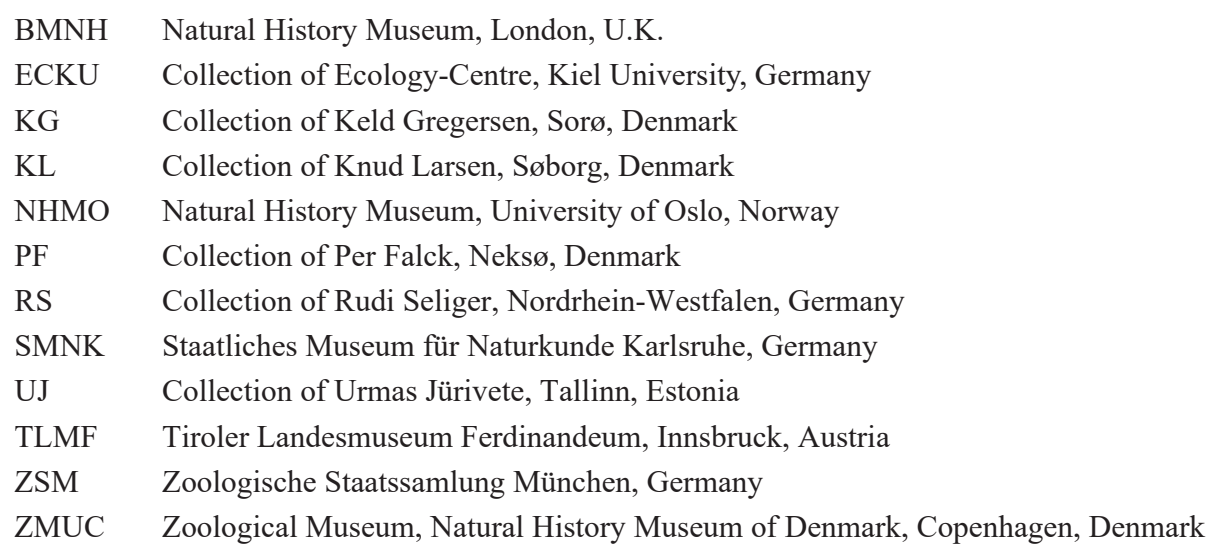

\section{Results}

Anarsia Zeller, 1839: 190.

Type species: Tinea spartiella Schrank, 1802.

Ananarsia Amsel, 1959: 32.

Type species: Anarsia lineatella Zeller, 1839.

The genus Anarsia has traditionally been considered as related to certain similar genera, e.g., Hypatima Hübner, 1825, in the subfamily Chelariinae (see, for example, Karsholt and Riedl 1996). Due to its peculiar morphology Amsel (1977: 233-235) erected a family Anarsiidae exclusively for Anarsia; however, this action was not supported by other researchers (Ponomarenko 2009: 24). 


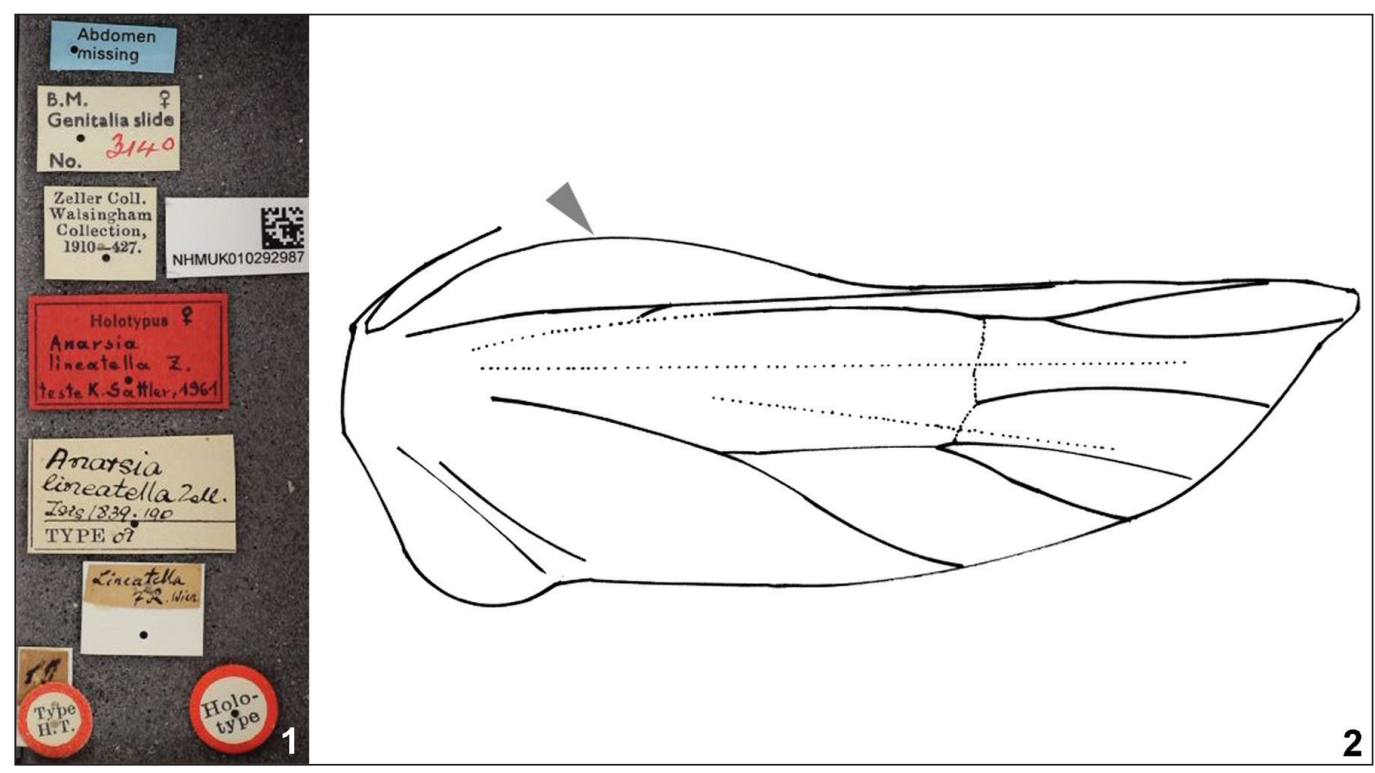

Figures 1, 2. 1. Anarsia lineatella, holotype, labels (foto D. Lees, by courtesy of the BMNH). 2. Anarsia innoxiella sp. n., hindwing with convex extension at proximal part of costa.

Ponomarenko (1997: 312) gave it the status of a tribe, but in a recent molecular study (Karsholt et al. 2013) Anarsia clustered together with Hypatima, Neofaculta Gozmány, 1955, and Nothris Hübner, 1825 in Chelariini of the subfamily Anacampsinae.

Many of the morphological specializations present in some or all Anarsia species (e.g., androconial scales, hair pencils, shape of labial palpi and hindwings and genital structure) are probably related to courtship, i.e., dispersal of pheromones and attracting of the opposite sex. This may explain why these striking characters are not reflected more strongly in the molecular analysis (Karsholt et al. 2013), which places Anarsia amongst more 'normal-looking' genera of Gelechiidae.

Anarsia is characterized by some remarkable morphological characters: vestigial segment 3 of labial palpus in male, hindwing with distinct convex elevation at proximal part of costa (Fig. 2), and presence of secondary wing locking mechanism, the 'frenum' (see Ponomarenko 1997); male genitalia asymmetrical, without gnathos, and valva with specialized palmate scales (Figs 3a, 4a); in female genitalia ostium bursae with widely different ventral and dorsal sides (see Fig. 4b, os-a and os-d) with antrum tilted, hence appearing asymmetrical.

These characters are not, or only rarely, found in any other of the 500 or so genera of Gelechiidae. At present Anarsia, as understood here, includes about 100 species (catalogued by Ponomarenko 2009: $339 \mathrm{ff})$. It is widely distributed in Eurasia and Africa.

Anarsia s.1. is morphologically diverse. An attempt to split the genus was made by Amsel (1959), who erected the genus Ananarsia for A. lineatella and related species based on the location of the spines on the valvae of the male genitalia. However, having examined additional species, he retracted Ananarsia as a separate genus and synonymised it with Anarsia (Amsel 1967: 25).

The structures on the valvae described as spines ("Dornen") (Amsel 1959, 1967) or processes (Ponomarenko 2009) are in fact tubes, characterized by being hollow and having a distal opening (Fig. 3b). We think that these tubes may be connected with glands and function in disseminating 


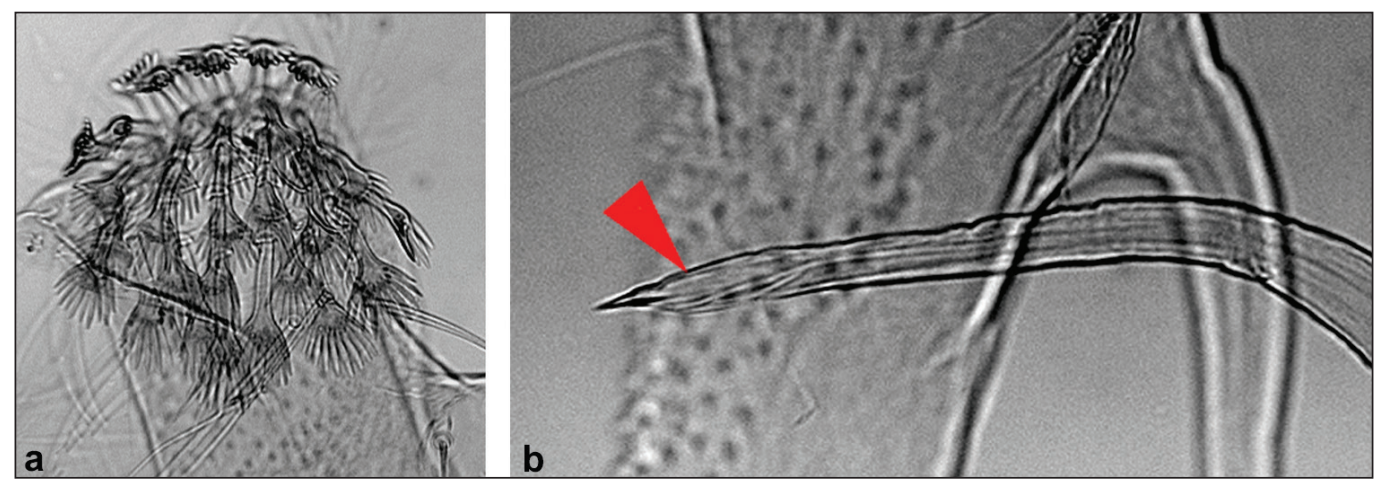

Figure 3. Anarsia male genitalia. a. Palmate scales at distal part of left valve; b. Tube at right valva with distal opening.

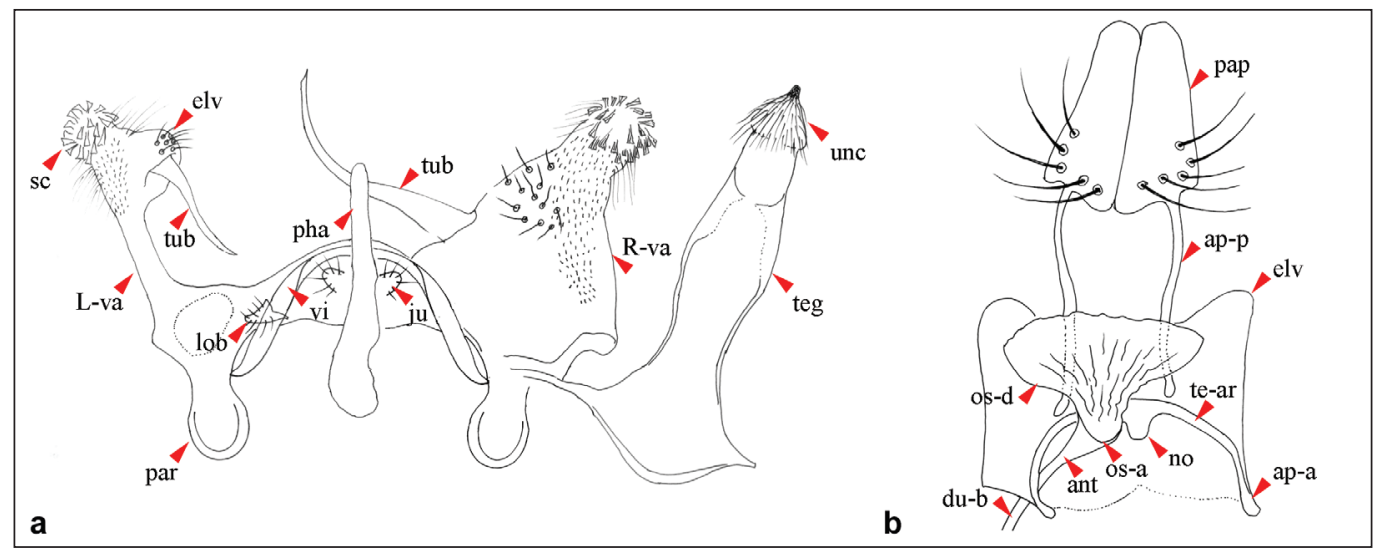

Figure 4. Anarsia genitalia (schematic). a. male, elv: elevation at left valva (sub-apical lobe); ju: juxta; L-va: left valva; lob: lobe at left side of vinculum; par: parategminal sclerite; pha: phallus; R-va: right valva; sc: scent scales (palmate); teg: tegumen; tub: tubular process; vi: vinculum. b. female genitalia (schematic); ant: antrum; ap-a: apophysis anterioris; ap-p: apophysis posterioris; du-b: ductus bursae; elv: elevation at segment VII; no: notch, pap: papillae analis; os-a: ostium bursae (anterior part); os-d: ostium bursae (dorsal part); t-ar: tergal arch.

male pheromones during courtship and mating. Ponomarenko $(2005,2008,2009)$ has described tubes at the vinculum in the tribe Litini (Gelechiidae) with a similar function, naming them glandiductors.

Ponomarenko retained Ananarsia at first as a subgenus (Ponomarenko 1989) and later (1992) as a separate genus. She restricted Anarsia to A. spartiella and related species based on characters in the genitalia: male phallus with blind base (coecum), so-called valvella reduced (see below under A. innoxiella), female with anterior lobe at tergum and lack of sack-like structure in segment VIII (Ponomarenko 1997). Whereas Anarsia sensu Ponomarenko may well be monophyletic, it leaves the morphologically diverse Ananarsia paraphyletic. Ponomarenko's view has not been followed by subsequent authors (e.g., Ueda 1997; Li and Zheng 1998; Bae et al. 2016) who kept Anarsia undivided; this is followed here. 


\section{Anarsia innoxiella sp. n.}

http://zoobank.org/F632AB41-2E16-4860-B207-47419F38972B

Holotype. ㅇ, Denmark, LFM, Flintinge, 9.vii.2002, leg. K. Gregersen, gen. slide Gregersen 3462 (ZMUC).

Paratypes. Bulgaria. Blagoevgrad prov., $5 \mathrm{~km}$ E Illindentsi, $880 \mathrm{~m}, 1$, , 7.viii.2012, leg. O. Karsholt (ZMUC); Burgas prov., Strandja, Zvezdets, Kovach, 350 m, 2今̄, 1ㅇ, 16-25.vi.2014, leg. H. Roweck \& N. Savenkov (ECKU); Kardzhali prov., Krumovgrad, 1ð̊, 9.vi.2005, leg. J. Buszko, gen. slide Karsholt 5243 (ZMUC). Croatia. Velebit Mt., 1 km W Brusane, 825 m, 1ô, 1, 27.vi.2003, leg. C. Hviid \& B. Skule, gen. slide Gregersen 1621, 1622 (ZMUC). Czech Republic. Bohemia, Srbsko, 1ð̄, la. 24.v.2000, Acer campestre, leg. O. Karsholt (ZMUC). Denmark. B: Øster Sømarken, 1ð̃, 5.vii.2006 \& 1ð̃, 5.vii.2008, leg.

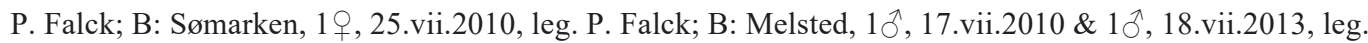
P. Falck; B: Grisby, 1ð̄, 11.vi.2011, leg. P. Falck; B: Årsdale, 1ð̄, 7.viii.2015, leg. P. Falck (all PF). LFM, Horreby Lyng, 1ठ, 20.vii.1960, leg. H. K. Jensen, gen. slide Jensen 589 (ZMUC), 1, 10.vii.2010, leg. K. Gregersen,gen. slide Gregersen 3463 (KG); LFM, Maltrup Skov, 1ð̊, 9.vii.1971, leg. K. Schnack (ZMUC); LFM, Sakskøbing, 19, 9.vii.1972, leg. K. Pedersen (ZMUC); LFM, Mellemskoven, 1ð̂, 5.viii.1972, leg. G. Pallesen (ECKU), 1ठ̄, 7.vii. 1973, G. Jørgensen, leg., gen. slide Gregersen 3361 (KG); LFM, Hanemose, 1ð̂, 11.vii.1975, leg. O. Karsholt (ZMUC); LFM, Frejlev Skov 1q, 3.vii.1976, leg. O. Karsholt (ZMUC); LFM, Møns Klint, 1ठ઼, 6.vii.1976, leg. K. Schnack, 1ठ઼, 13.vii.1985, leg. H. Hendriksen, gen.

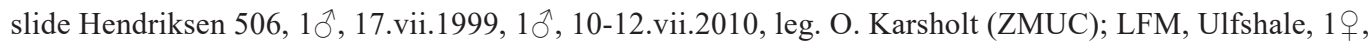
8.vii.1977, K. Schnack, gen. slide Gregersen 1629 (ZMUC); LFM, Blans Skifter, 1ठ, 7.vii.1983, leg. K. Gregersen, gen. slide Gregersen 1585 (KG); LFM, Vålse Vesterskov, 1へ̂, 1q, 30.vii.1984, leg. K. Gregersen (KG), 1ठ, 1.vii.1993, leg. H. K. Jensen (ZMUC); LFM, Stubbekøbing, Rodemark, 1ð̂, 31.vii.1984,

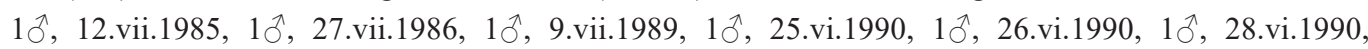

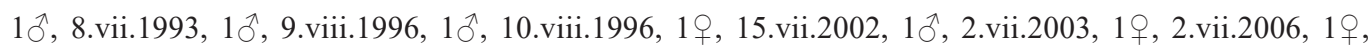
4.vii.2009, leg. A. Madsen (KG, ZMUC); LFM, Næsgård Landbrugsskole, 1ðં, 26.vi.1989, leg. A. Madsen (ZMUC); LFM, Roden Skov, 19, 8.vii.1989, leg. K. Gregersen, gen. slide Gregersen 1594 (KG); LFM Løgnor, 2ð, 30.vii.1991, 4ð, 4.vi.1992; leg. H. K. Jensen (ZMUC); LFM, Jydelejet, 1ठ઼, 9.vii.1992, leg. H. K. Jensen (ZMUC); LFM, Korselitse Østerskov, 1ð̄, 19-25.vii.1992, leg. G. Jeppesen \& K. Larsen (KL); LFM, Guldborg Storskov, 1ð̄, 8.vii.1993, leg. A. Madsen (ZMUC); LFM, Fuglsang, Skejten, 1ð, 1ㅇ, 15.vii.1993, leg. M. Stoltze \& O. Karsholt, gen. slide Hendriksen 2094 (ZMUC); LFM, Hamborgskoven, 2ð, 14.vii.1995, leg. K. Gregersen, gen. slide Gregersen 0943, 1ð, 3.vii.2010, leg. K. Gregersen

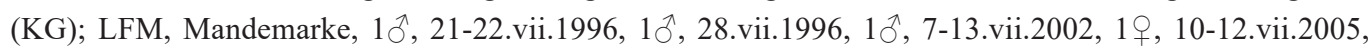

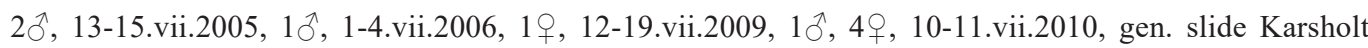
5247, 4ㅇ, 12-13.vii.2010, 1q, 16.vi.2010, gen. slide Karsholt 5211, 1ठ, 15.vii.2010, gen. slide Karsholt

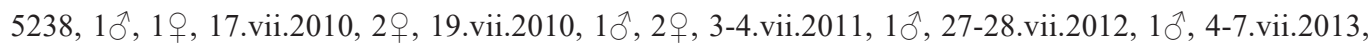

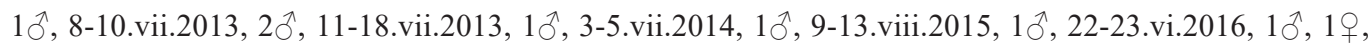
22-29.vii.2016, leg. O. Karsholt (ZMUC); LFM Faksehule Fyr, 1ðં, 9.vii.1999, leg. B. Baungaard, gen. slide Gregersen 3286 (KG); LFM, Hesnæs Havn, 1ð̊, 18.vii.2002, leg. K. Gregersen, gen. slide Gregersen 3079 (KG); LFM, Møns Klint syd, 1ठ̋, 10-12.vii.2010, leg. O. Karsholt (ZMUC); LFM, Rødbyhavn, 1q, 5.vii.2014, gen. slide Gregersen 3359; 1 , , 6.vii.2014, leg. K. Gregersen (KG). NEZ, Gentofte, Dyssegård, 1ð̋, 18.vii.1968, leg. C. Aastrup, gen. slide Hendriksen 762 (ZMUC); NEZ, Søborg, 2ð̂, 10.vii.1976, leg. K. Schnack (ZMUC); same locality but 1 + , 13.vii.2001, leg. K. Larsen \& B. Martinsen (KL); NEZ Høje Taastrup, 1ठ, 11.vii.1981, J. P. Baungaard, gen. slide Gregersen 3292 (KG); NEZ, København Ø, $1 \hat{\jmath}$, 24-25.vi.1992, 2ð, 26-28.vi.1992, 1ठิ, 10-13.vii.1995, 1ठิ, 24-25.vii.1996, gen. slide Hendriksen 6266, 
1, 14-15.viii.1996, gen. slide Hendriksen 6269, 1ð, 22-23.vii.1997, gen. slide Hendriksen 6267, 1ð, 2-4. vii.1999, gen. slide Karsholt 5240, 1ठ, 20-23.vii.2001, 1, 28-29.vii.2004, 1ㅇ, 3-10.vii.2009, leg. O. Kars-

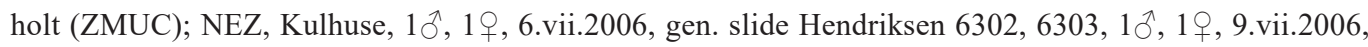
leg. H. Hendriksen (ZMUC). NWZ, Føllenslev, 1ð̄, 29.vii.2006, 1ð̂, 4.vii.2008, leg. E. Palm, gen. slide Gregersen 1964 (EP); NWZ, Slagelse, 1§̋, 9.vii.2002 gen. slide Gregersen 1586, 1q, 27.vii.2007, gen. slide Gregersen 3360, 1, 1.viii.2010, leg. K. Pedersen, gen. slide Gregersen 3090 (KG); NWZ, Røsnæs, 1 \%, 12.vii.2005, leg. U. Seneca, gen. slide Gregersen 3368 (KG). SZ, Højstrup, 1ð̊, 9.vi.1959, leg. H. K. Jensen [1th Danish specimen]; SZ, Jungshoved, 1§ึ, 5.vii.1959, gen. slide Wolff 2359, 3ô, 12.vii.1964, gen. slide

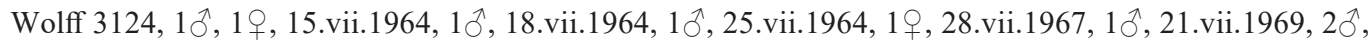

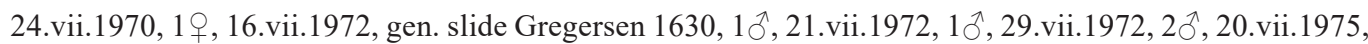

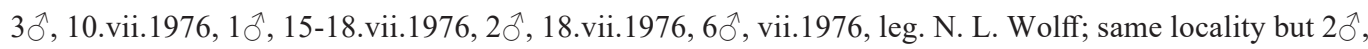
1.-7.vii.1981; 7ठ, 1 , 8-14.vii.1981, gen. slide Karsholt 4178; 1ð, 14.vii.-13.viii.1991, leg. O. Karsholt (ZMUC); SZ, Glænø, 1ð, 18.vii.1983, leg. H. K. Jensen (ZMUC); SZ, Præstø, 2ð̊, 11-14.vii.1991, 1ð, 1ㅇ, 27.vi.-1.vii.1992; 1q, 8-11.vii.1992, gen. slide Hendriksen 6301; 1q, 15-27.vii.1993, leg. O. Karsholt (ZMUC); SZ, Vemmetofte, 2ð’, 18.vii.2005, leg. K. Gregersen (KG); SZ, Sorø By, 1ðึ, 13.vii.2006, gen. slide Gregersen 1587, 1ð̂, 26.vi.2011, leg. K. Gregersen (KG); SZ, Sorø Sønderskov, 1ð̊, 30.vi.2009, leg. K. Gregersen (KG). France. Provence, Domain de Maura Vieille, 1ð̊, 5.x.2002, leg. H. Hendriksen, gen. slide Gregersen 3427 (ZMUC); Provence, Castellane, 2Ô, 18.vi.2012, leg. E. Palm, gen. slide Gregersen 3344, 3350 (EP). Germany. Baden-Württemberg, Marback am Neckar, 1, 3.vii.1973, leg. L. Süssner (TLMF); Hessen, Zwergen, 1ㅇ, 10.vi.2000, leg. H. Retzlaff (ECKU); Niedersachsen, Witzendorf, $1{ }^{\lambda}$, 27.vii.2008. leg. C. Kayser, gen. slide Gregersen 1924 (KG); Northrein-Westphalen, Weserbergland, Biesterberg, Lemgo, 1§, 1q, 27.vi.2003, leg. H. Retzlaff (ECKU); Rheinland-Pfalz, Vulkaneifel, Gillenfeld, NSG Strohner Märchen, 19, 18.vi.2005, leg. R. Seliger, gen. slide Gregersen 3086 (RS); Thüringen, Bad Blankenburg, 1ㅇ, 18.vi.1976, leg. H. Steuer, gen. slide Gregersen 3349; same data but, Muschelkalk, $1 \overbrace{}^{\text {, }}$ 25.vi.1989 (ECKU). Greece. Evros, Avandas Gorge, 100 m, 19, 29.vi.2004, leg. B. Skule; Florina, Limni Mikra Prespa, near Karies, 1025 m, 1ðð, 24.vi.2004, leg. B. Skule; Lakonia, waterfall by Nomia-Lyra, 1 , 1.vi.1979, leg. G. Christensen \& L. Gozmány; Lakonia, 7 km SW Monemvasia, 150 m, 1 ô, 19, 17.vi.1980, 3 우 우 2.vii.1982; 1ð , 24.vi.1980 26.vi.1981, leg. G. Christensen; Sérres, Kalókastro, 1우, 25.vi.1997, leg. Z. Laštůvka (all ZMUC). Hungary. Leanyfalu, 1 + , 5-10.vii.1997, leg. B. S. Larsen (ZMUC). Italy. Piemonte (CN), Parco Naturale Regionale Alpi Maritime, Valdieri, 900 m, 1, 17.vii.1999, leg. G. Baldizzone (ZMUC). Nederlands. Twello, 19, 16.vi.2002, leg. J. Wolschrijn (ZMUC). Norway. Ø, Sarpsborg, Tune, Råkil, 1ठ̂, 15.vii.2011, leg. T. J. Olsen (NHMO). Romania. Mehedinţi, Dubova, 2o, 10.vi.1993, leg. L. Rakosy (ZMUC); Caraö-Ceverin, 5 km NW Sasca Montanâ, 250 m, 1ð̄, 1ㅇ, 14.vii.2005, leg. C. Hviid, B. Skule \& E. Vesterhede (ZMUC). Slovakia. Zvolen, 1Ô, la. v.1979, Acer campestre, gen. slide Karsholt 5242, Domaniky, 2q, la. vi.1979, Acer campestre, leg. J. Patočka (ZMUC); Slovenský Kras, Zadiel, 1 ㅇ, 24.vii.1992, leg. K. Larsen (ZMUC); Sliepkovce, 1ð̊, 8.vi.1963, leg. K. Krušek (ECKU). Turkey. Edirne, Keşan, 1 \% , 5.vii.1987, leg. E. Baraniak (ZMUC).

Material not included in the type series (see also below under Remarks). Cyprus (Southern part). N of Limasol, Moniatis, 650 m, 19, 23-29.vi.1997, leg. M. Fibiger, A. Madsen, D. Nilsson \& P. Svendsen; Trodos Mts., Platres, 1200 m, 7ðૈ, 4q, 11-16.v.1999, leg. C. Hviid \& B. Skule, gen. slide Gregersen 1623, 1624, 3417;

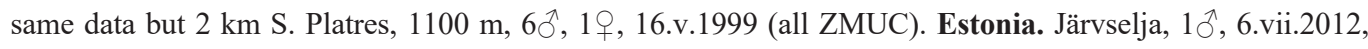
leg. E. \& U. Jürivete (UJ). Greece, Crete. Omalos, 1200 m, 1q, 25-30.vi.2000, leg. M. Fibiger, A. Madsen, D. Nilsson \& P. Svendsen, gen. slide Gregersen 3420; Crete W, Kallergi Mts., 1450-1550 m, 1ㅇ, 28-30. vii.2001, leg. M. Fibiger, A. Madsen, D. Nilsson \& P. Svendsen; Chania, N of Omalos plaeau, at pass, 1150 
m, $1 \hat{\jmath}$, 7.vi.2004, leg. C. Hviid, B. Skule \& E. Vesterhede; Omalos Plateau, 1040 m, $3{ }^{\curvearrowright}$, 15 9 , 15-20.vi.2014, leg. C. Hviid, O. Karsholt, F. Vilhelmsen, gen. slides Gregersen 2ð 3436, 3438; 2 \% 3437, 3439 (ZMUC); Omalos Plateau, road to Kaligeri, 1225 m, 4ð̊, 9 9 , 15-20.vi.2014, leg. C. Hviid, O. Karsholt, F. Vilhelmsen (all ZMUC). Latvia. Daugaupils distr., Silene, 1ㅇ, 15-19.viii.2002, leg. N. Savenkov, gen. slide Gregersen 3141; same data but, Silene, Ilgas, $3 \hat{\partial}$, 1 q , 11-15.vi.2007, gen. slide Gregersen 3085, 3347, 3395 3348; same data but Silene, Ilgas, 1, 24.vi.2013, gen. slide Gregersen 3396 (all ECKU). Spain. Alicante, Parcent, 450 m, 1, 14.v.2013, leg. H. Rietz (ECKU); Málaga, 14 km W Algeciras, 200 m, 1ð̋, 23-24.ix.1973, leg. M. \& W. Glaser, gen. slide Gregersen 3422 (ZMUC); Málaga, Sierra de Marbella, El Mirandor, 1ðึ, 19.viii.1977, 1ठ, 28.x.1983, leg. E. Traugott-Olsen, gen. slide Gregersen 3423, 3424 (ZMUC); Málaga, Camino d. Rhonda, 1ð̄, 23 v.1986, leg. E. Traugott-Olsen, gen. slide Gregersen 3421 (ZMUC).

Diagnosis. Anarsia innoxiella is characterized by its whitish grey and blackish grey forewings, which bear black longitudinal streaks, with the streak in the middle of the wing being especially prominent. It is similar to $A$. lineatella, but that species can be distinguished by the broadly longitudinal black spot followed by white in the middle of the wing ( $A$. innoxiella has a straighter black streak here). A. innoxiella shows some variation from light, variegated specimens to darker moths approaching A. lineatella in appearance. Several other Anarsia species have wing markings similar to the two species dealt with in this paper, e.g., A. acaciae Walsingham, 1897 (Amsel 1967: 23), but they differ in genitalia characters. Males of $A$. acaciae have a pencil of long, black hairs on the base of the hindwing costa.

The genitalia of $A$. innoxiella are similar to those of $A$. lineatella. The male of $A$. innoxiella can be separated from the latter by 1 ) the sub-triangular sub-apical lobe of the left valva being less protruding in A. lineatella; 2) the conic, triangular uncus being slightly more slender in A. lineatella; and 3 ) the moderately broad tegumen with weakly sinuous lateral margins.

In the female genitalia the ridges from the middle of a sclerotised arch of tergum VIII are distinct in A. lineatella, but absent or very weak in A. innoxiella.

Description. Adult (Fig. 5a-d). Male. Wingspan 13-15 mm. Segment 2 of labial palpus with sub-rectangular scale tuft, black, mottled with whitish grey on upper and inner surface; segment 3 reduced. Antenna light grey, ringed with black. Head light grey mottled with dark grey; frons cream-white; thorax grey, laterally darker; tegula dark grey. Ground colour of forewing whitish grey; dorsally basal part overlaid with blackish grey; costa with small blackish grey spot at $1 / 6$, and two larger spots at 1/4 and 1/3; one distinct longitudinal black spot in middle of wing; veins with black scales interrupted by white; fringe grey, speckled with light grey and with darker fringe lines. Hindwing grey with grey fringe. Female. Segment 2 of labial palpus with distinct ventral brush; segment 3 longer than 2, narrow, whitish grey with two black rings. Otherwise similar to male.

Variation. There is some variation in the amount of blackish grey scales in the forewing. The above description is based on specimens from northern Europe (mainly Denmark and north Germany). Specimens from north-eastern Europe are larger $(15-16 \mathrm{~mm})$ and have the forewings more uniformly covered with dark grey scales (thereby restricting the white scales) whereas the black stripes are prominent, giving the wing a striped appearance. Such (more or less) dark grey, black-striped specimens also occur as an individual form from other East European countries. Specimens from mountain localities in Crete and Cyprus are externally similar to northern European specimens.

Male genitalia (Figs 6, 10a, b). Tergum IX-X truncate, medium in breadth, lateral margins moderately sinuous; uncus regularly triangular, apex tapered with tiny, pointed, distal tip; gnathos and 


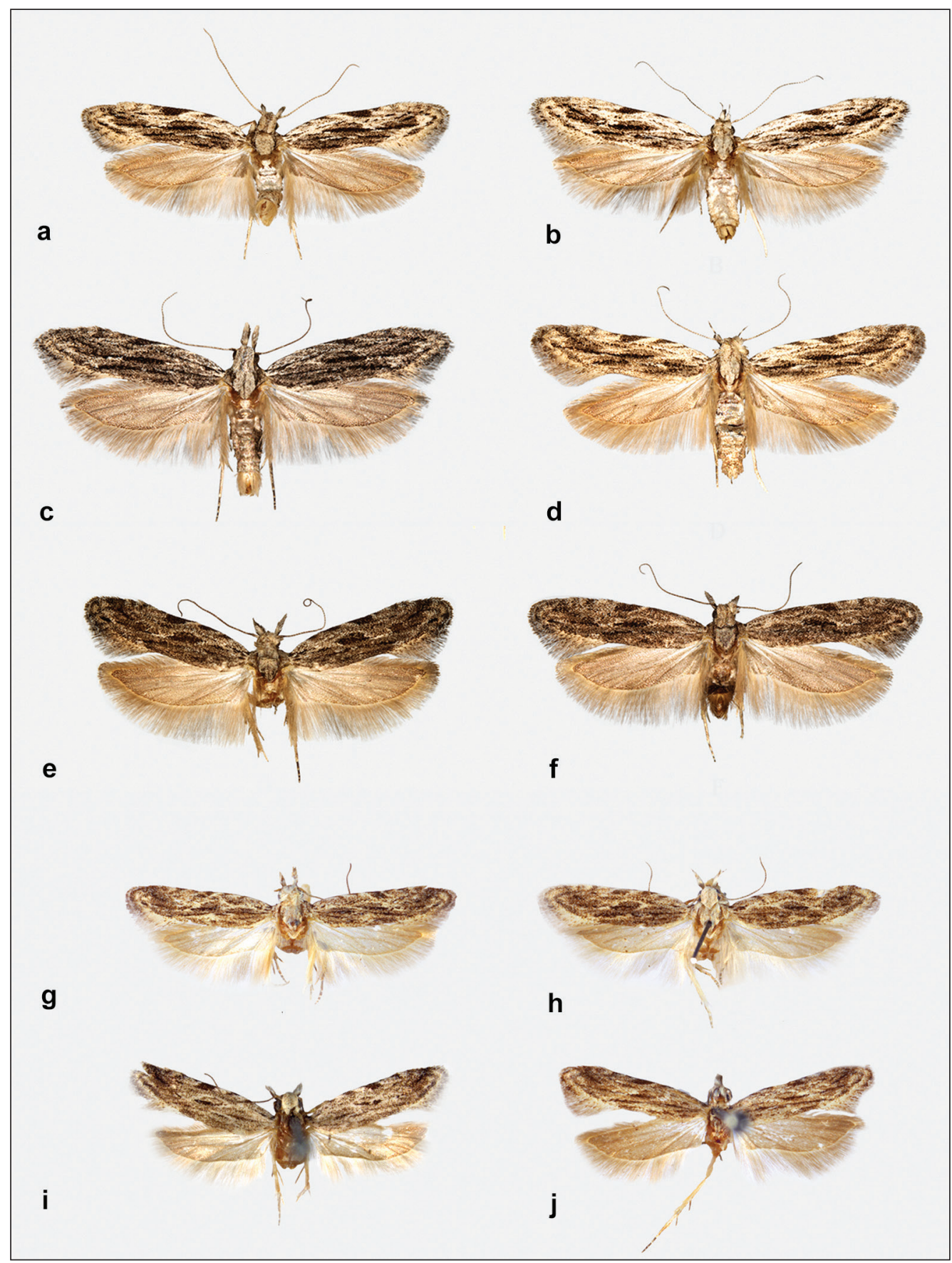

Figure 5. Anarsia adults. a. A. innoxiella sp. n., Denmark (KG); b. A. innoxiella sp. n., Holotype, Denmark (ZMUC); c. A. innoxiella sp. n., Latvia (ECKU); d. A. innoxiella sp. n., Germany (ECKU); e. A. lineatella Zeller, Germany (KG); f. A. lineatella Zeller, Germany (ECKU); g. A. lineatella ssp. heratella Amsel, Afghanistan (SMNK); h. A. lineatella ssp. heratella Amsel, Afghanistan (SMNK); i. A. lineatella ssp. tauricella Amsel, holotype, Turkey (ZSM); j. A. lineatella ssp. tauricella Amsel, paratype, Turkey (SMNK). 


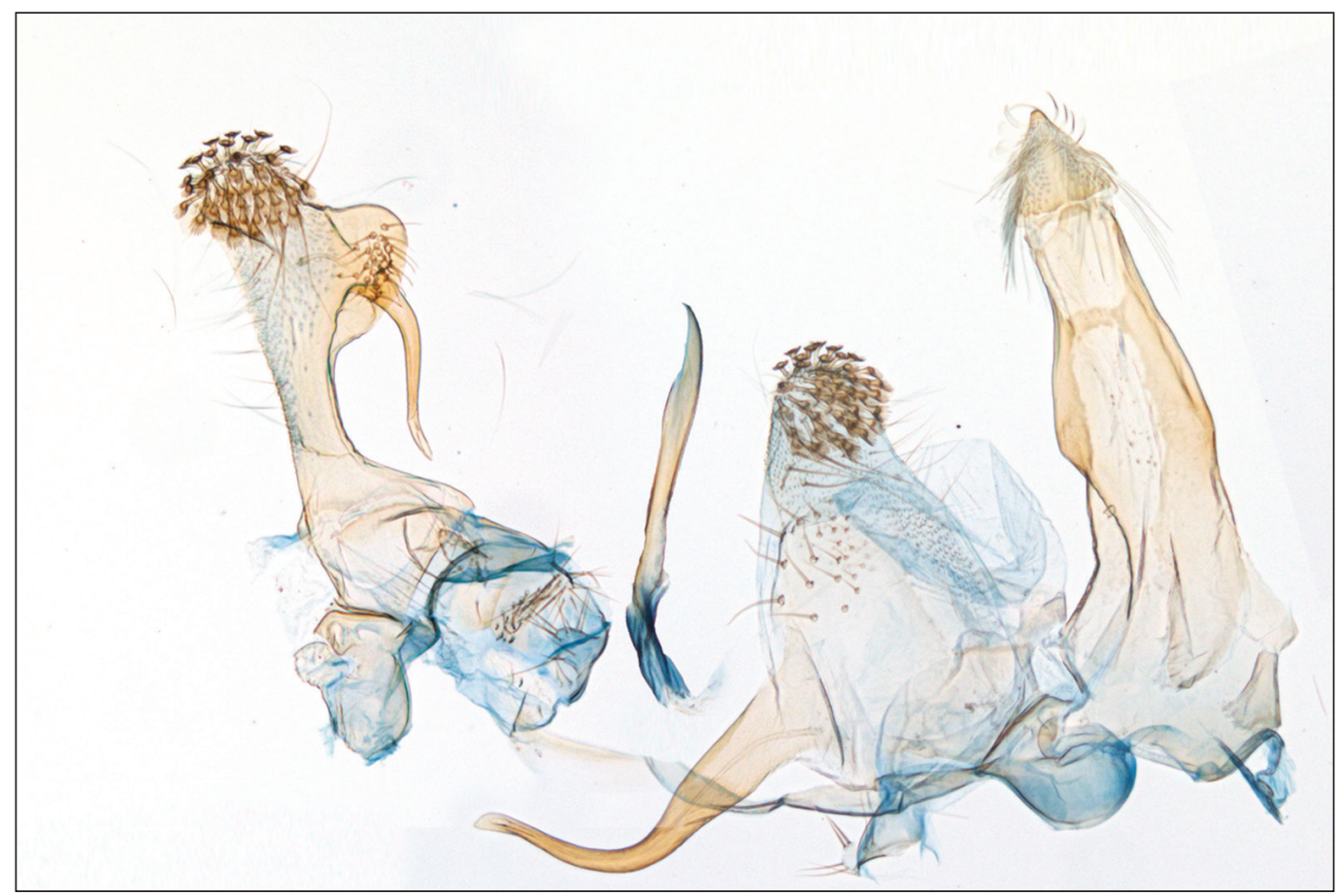

Figure 6. Anarsia innoxiella sp. n., male genitalia, Slovakia (OK5242).

culcitula absent; parategminal sclerites almost round and lacking coremata; sternum IX strongly asymmetrical, left valva truncate, sub-apical lobe protruding, usually somewhat up-turned, bearing long slender, pointed tubular process; right valva large, broadly sub-triangular, bearing very long, pointed, moderately curved, tubular process; single small, sub-triangular, slightly setose lobe near vinculum on left side (valvella sensu Ponomarenko 2009), juxta lobes small, setose; phallus ankylosed to juxta, tubular without coecum, trunk flat, bent dorsally, apex rounded.

Female genitalia (Figs 7a, 8, 9a, b). Papillae anales elongate, apophyses posteriores moderate in length; apophyses anteriores very short; segment VIII cylindrical, evenly sclerotised, with a pair of slight, distal elevations; strongly sclerotised concave arch at anterior margin of tergum with medial notch; distal ridges from middle of tergal arch absent or faintly indicated; antrum tilted, funnel-shaped; ostium bursae with ventral part crescent-shaped, sharply defined, dorsal part wrinkled, widely extending caudad; ductus bursae slender, straight; colliculum absent; ductus seminalis arising from transition between ductus and corpus bursae; signum plate sub-rectangular, with strongly serrate margins. Sac-like formation in segment IX anteriad of papillae anales and similar formation distad of segment VII.

Bionomics. The larva is dark reddish-brown with small pinacula, bearing white hairs; head and prothoracic plate small, glistening black; anal plate black (description based on photograph of larva of "A. lineatella" at Lepiforum 2016). It is similar to that of $A$. lineatella. It feeds between fresh leaves of Acer campestre L. (Lepiforum op cit. - as "A. lineatella"). Lepiforum also refers to "Ahorn" (=Acer L.) as host plant for this species, and it is well possible that the larva of A. innoxiella feeds on more than one Acer-species. The species has also been reared from larvae 


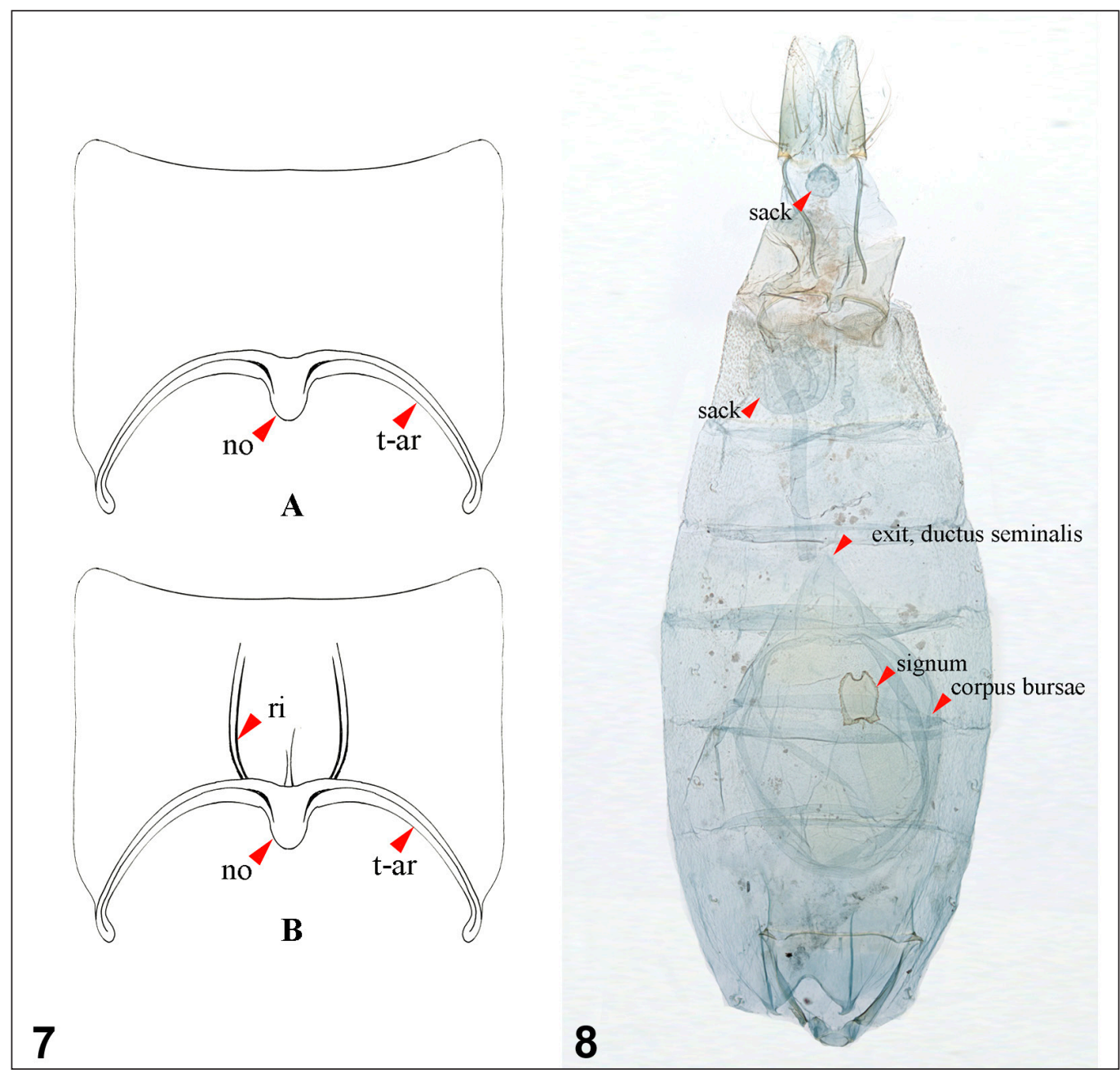

Figures 7, 8. 7. Anarsia female genitalia, tergiteVIII (schematic). a. A. innoxiella sp. n.; b. A. lineatella. no: notch; ri: ridges; t-ar: tergal arch. 8. A. innoxiella sp. n., female abdomen (KG3368).

found on Acer campestre in the Czech Republic and in Slovakia (see list of examined material). In Crete $A$. innoxiella was caught in numbers in light traps placed among Acer sempervirens L. $A$. innoxiella occurs in a wide range of biotopes, such as deciduous woods, hedgerows, and gardens. Univoltine. Adult from mid-June to mid-August. Larva from April to June. The species is mostly collected at light.

Distribution. A. innoxiella is widespread in Europe and locally common, but in view of its previous confusion with $A$. lineatella our knowledge of its distribution is still incomplete. It is found in Scandinavia, where it was recently (2015) recorded in Norway (L. Aarvik in litt.), and is known from Denmark, southern and middle Sweden (Gustavsson 2017), and southern Finland (M. Mutanen in litt.); it is also recorded from the three Baltic countries. In addition to the countries from 


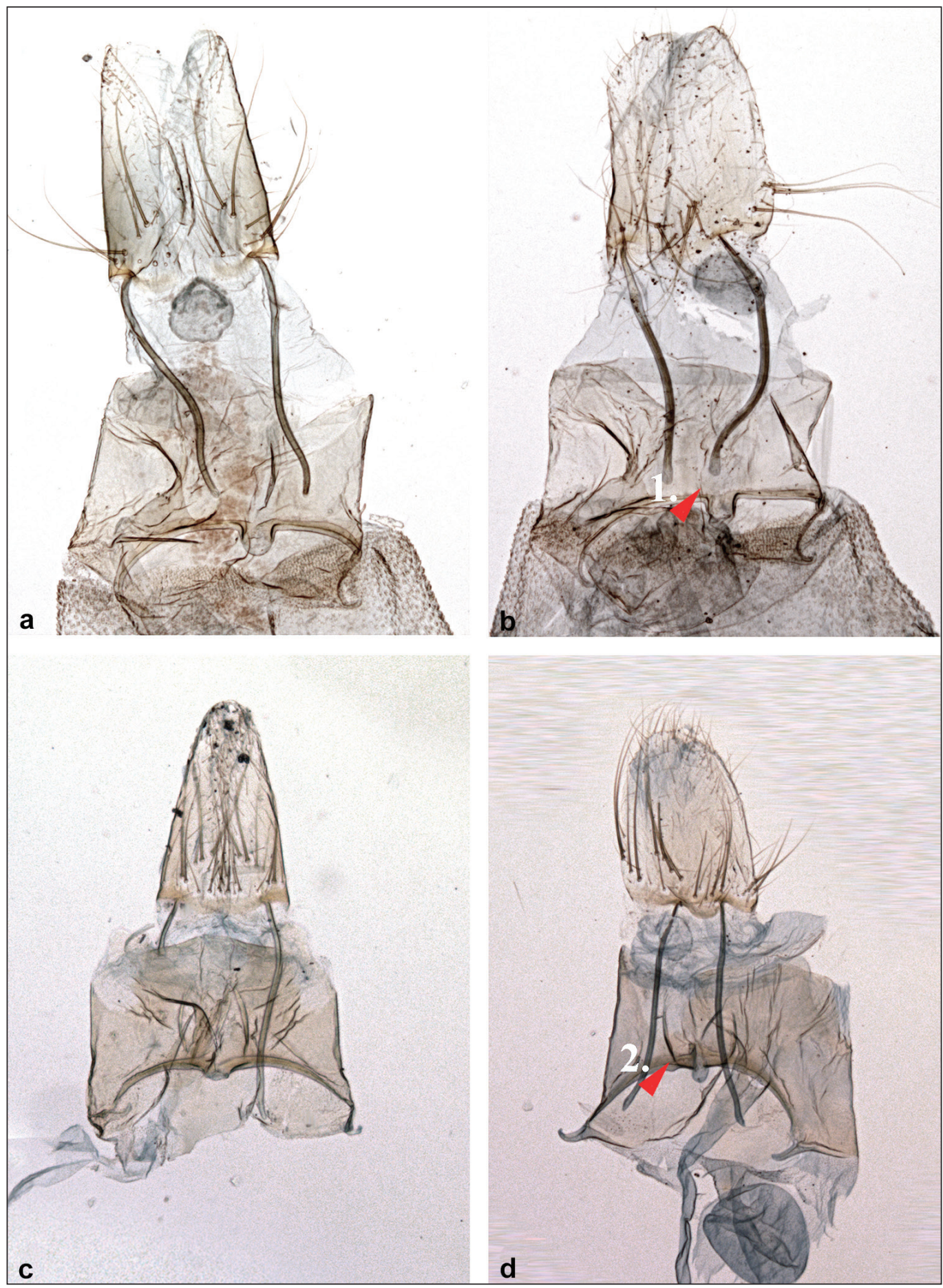

Figure 9. Anarsia female genitalia. a, b. A. innoxiella sp. n. (KG3368, KG3360); c, d. A. lineatella (KG3335, KG3341). 1. ridges absent; 2. ridges present. 


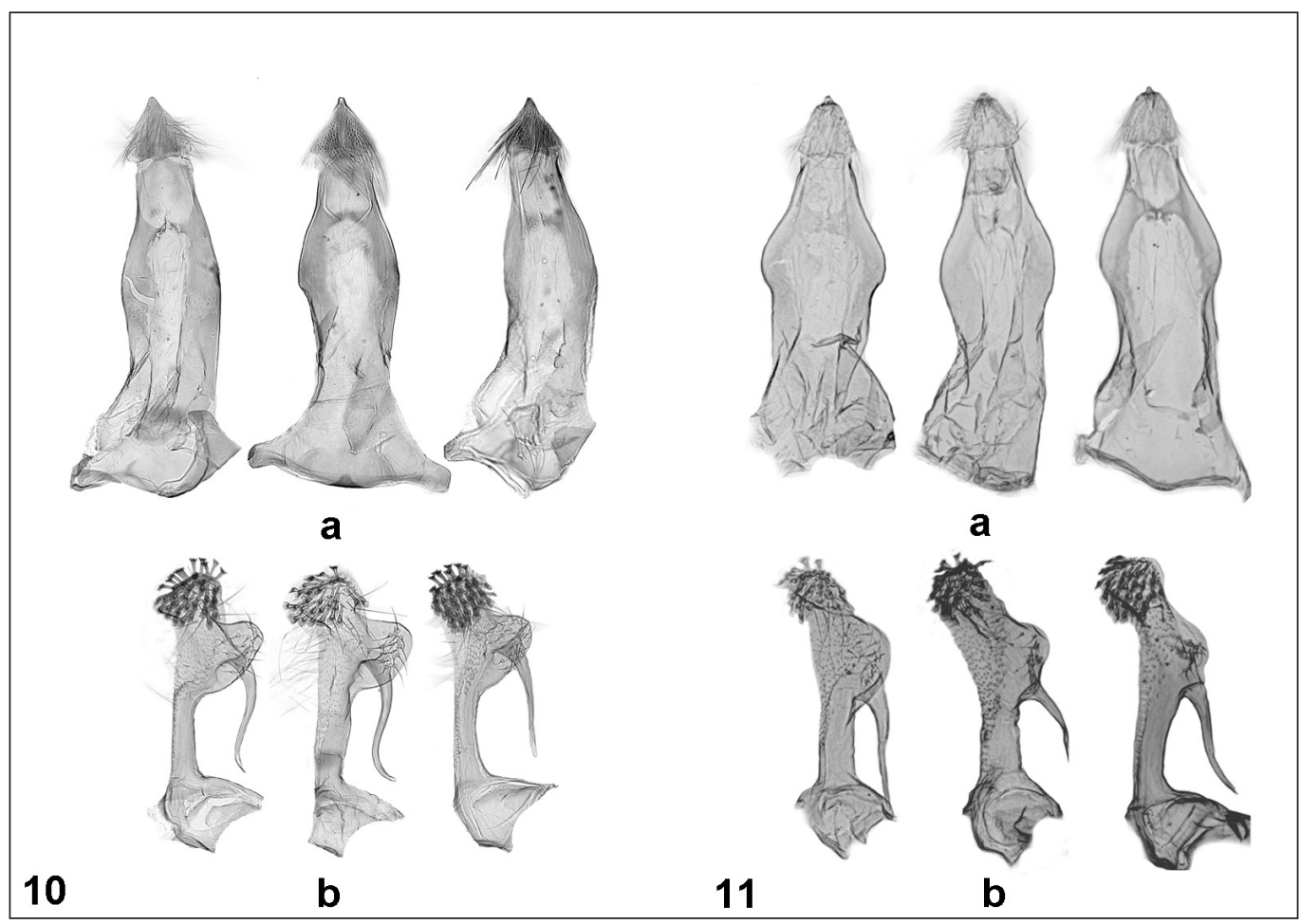

Figure 10-11. 10. A. innoxiella sp. n.; variation of male genitalia (HH6266, HH6303, OK5040). a. tegumen; b. left valva. 11. A. lineatella; variation of male genitalia (KG935, KG3349, KG3365). a. tegumen; b. left valva.

where we have examined specimens we can also confirm the presence of A. innoxiella in Austria (Lepiforum 2016), Great Britain (Lewis 2016), and Poland (T. Rynarzewski in litt.).

Etymology. The species name "innoxiella" is a composite word formed from the Latin adjective innoxia $=$ harmless, innocuous (in contrast to $A$. lineatella), and the diminutive suffix -ella . The name is to be treated as a noun in apposition.

Remarks. Specimens of $A$. innoxiella from north-eastern Europe differ in external characters from other specimens treated here (as described above under 'Variation'), but they have similar genitalia. It is unclear if the north-eastern form differs due to geographical isolation (thus representing a subspecies), if it is a result of the climate (i.e., short summers and/or cold winters), or if it is due to difference in the foodplant (the north-eastern population probably feeds on Acer platanoides L., the only native Acer in that area). Due to these uncertainties we have excluded such specimens from the type material - and for the same reasons we refrain from using them to describe a subspecies. Specimens with intermediate colour and wing markings occur among typical specimens further south in eastern Europe.

The few specimens examined from southern Spain are generally smaller and paler than typical A. innoxiella and are likewise excluded from the type series. Also, specimens from mountain localities in Crete and Cyprus are - in spite being externally very similar to North European specimens - excluded from the type series due to slight differences in the genitalia. 


\section{Anarsia lineatella Zeller, 1839}

Anarsia lineatella Zeller, 1839: 190 (nomen protectum)

Tinea pullatella Hübner, 1796: 63, pl. 17, fig. 118 (nomen oblitum)

Anarsia? pruniella Clemens, 1860: 169.

Anarsia lineatella heratella Amsel, 1967: 20. Subspecies.

Anarsia lineatella tauricella Amsel, 1967: 20. Subspecies.

Type material. A. lineatella, holotype, + , with 9 labels (Fig. 1).

A. lineatella heratella, holotype, ơ: "AFGHANISTAN Herat 970 m 5.5.1956 H. G. Amsel leg." "Holotypus $\delta$ leg H. Amsel Anarsia lineatella heratella”| “Gen. præp. nr. 5296ð, O. Karsholt”. Paratypes. $3 q$, same data as holotype but genitalia slide 5295, 5297 (LNK).

A. lineatella tauricella, holotype, §̊: "Syr. sept. Taurus D Marasch VI 29"| "Holotypus § leg. H. Amsel

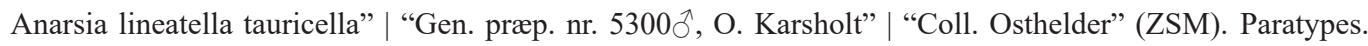
1ㅇ, "Syria sept. Taurus Marasch 1200 m 19.V.1928 L. Osthelder leg." |"AlloTypus $q$ leg. H. Amsel Anarsia lineatella tauricella" | "Gen. præp. nr. 5301, O. Karsholt” | "561” (ZSM); 1ठ, same data as holotype, but genitalia slide 3868 (LNK).

Other material studied. Bulgaria $(3 \hat{\partial}, 7 \uparrow)$, Cyprus $(1 \hat{\jmath}, 1 \uparrow)$, Denmark (4ㅇ) (introduced), Germany $(4 \hat{\jmath}$, 10 우), Greece $(4 \hat{\jmath}, 7$ 우), Hungary $(5 \hat{\jmath}, 1+$ ) $)$, Israel $(1 \hat{\jmath})$, Libya $(2 \hat{\jmath}, 1$ 우), Morocco $(3 \hat{\jmath}, 4$ 우), Romania $(1 \hat{\jmath})$, Spain $(7 \hat{\jmath}, 2+$ ), Spain, Canary Islands $(1+$ ), Turkey $(2 \hat{\jmath}, 1+$ ), Ukraine $(1 \hat{\jmath})$.

Diagnosis. Anarsia lineatella is characterized by its fuscous grey forewing with only a little white and with indistinct black streaks; it appears darker than $A$. innoxiella and has a less fractured pattern of the forewings. For separation from $A$. innoxiella see under that species.

The male genitalia are characterized by 1) the flatly rounded shape of the sub-apical lobe of the left valva, 2) the rather slender shape of the uncus, and 3 ) the comparatively broad tegumen with its distinctly sinuous margins. These characters separate $A$. lineatella from $A$. innoxiella. The female genitalia differ from those of $A$. innoxiella by having two or three distinct ridges articulating distad from the middle of a sclerotised arch of the tergum.

Description. Adult (Fig. 5e, f). Male. Wingspan 11-15 mm. Segment 2 of labial palpus with sub-rectangular scale tuft, black, mottled with whitish grey on upper and inner surface; segment 3 reduced. Antenna light grey, indistinctly ringed with blackish grey. Head light grey mottled with dark grey; frons lighter; thorax and tegula dark grey. Forewing fuscous grey, mottled with some light grey; costa with five small blackish spots separated by whitish grey, the spot at 1/2 most distinct; a broadly elongate black spot in middle of wing followed by white; veins with interrupted black scales; fringe whitish grey at base, darker grey beyond black fringe line. Hindwing grey with grey fringe. Female. Segment 2 of labial palpus with a distinct ventral brush; segment 3 longer than segment 2 , thin, whitish grey with broad, black ring in middle and some black at base and tip. Otherwise similar to male.

Variation. The nominotypical subspecies is rather uniform, showing only slight variation. Segment 3 of the labial palpi in females can have more or less black. The wingspan of a series of specimens of both sexes from Morocco is smaller than average (11-12 mm), but otherwise similar to European specimens. Specimens from Afghanistan (A. lineatella subsp. heratella) are characterized by having head, thorax, and basal half of the antennae whitish. The wing markings are similar to those of typical A. lineatella, but the forewings are somewhat bi-coloured, having a 
lighter costal third and a darker dorsal two-thirds. Specimens from southern Turkey are relatively small (about $11 \mathrm{~mm}$ ) and generally paler grey compared with typical A. lineatella. Such specimens have been described as $A$. lineatella subsp. tauricella. See also under 'Remarks' below for these two subspecies.

Male genitalia (Figs 11a, b, 12a). Tergum IX-X truncate, rather broad, lateral margin distinctly sinuous; uncus conical, comparatively slender, with tiny distal tip; gnathos and culcitula absent; parategminal sclerites almost round, without coremata; sternum IX strongly asymmetrical, left valva truncate, sub-apical lobe flatly rounded, bearing long, slender, pointed tubular process; right valva large, broadly sub-triangular, bearing very long, pointed, moderately curved, tubular process; single small, sub-triangular, slightly setose lobe near vinculum on left side, juxta lobes small, setose; phallus ankylosed to juxta, without coecum, phallic trunk flat, bent dorsally, apex rounded.

Female genitalia (Figs 7b, 9c, d). Papillae anales elongate, apophyses posteriores moderate in length; apophyses anteriores very short; segment VIII cylindrical, evenly sclerotised, laterally slightly elevated; strongly sclerotised concave arch at anterior margin of tergum medially notched; two or three distinct ridges articulate distad from middle of arch at tergum, extended to middle of segment; antrum tilted, funnel-shaped; ostium bursae with ventral part crescent-shaped, sharply defined, dorsal part wrinkled, widely extended caudad; ductus bursae slender, straight; colliculum absent; ductus seminalis arising from transition between ductus and corpus bursae; signum sub-rectangular plate with strongly serrate margins; sac-like formation in segment IX anteriad of papillae anales - and similar formation distad of segment VII.

Bionomics. The larva has (the rather small) head and prothoracic plate glistening black; the body is honey-brown or chestnut brown, with intersegmental divisions whitish; pinacula small, black, each with one whitish hair; anal plate glistening black; prolegs concolorous with body (Fischer von Röslerstamm 1842; Heckford 1992).

The species feeds on a number of Rosaceae, especially Prunus L. species. CABI (2016) lists Prunus armeniaca L., P. domestica L., P. dulcis (Mill.) D.A. Webb, P. persica (L.) Batsch and $P$. salicina Lind. as main host plants, and additionally Malus domestica Borkh. and Pyrus communis L. Piskunov (1990: 974) adds Prunus cerasus L. and P. spinosa L. He also lists Diospyros (Ebenaceae), which is an unlikely host plant of A. lineatella, and Acer tataricum L., which is probably a host plant of $A$. innoxiella. According to Piskunov (1990: 974, 899, fig. 611.3) the larvae of $A$. lineatella have also been reported to consume galls of the plum gall mite (Eriophyes phloecoptes Nal.).

In early spring the young larva of the first brood bores into a shoot from below the pith and hollows it out causing exudation of some sap; the shoot withers and the larva moves to a new one. Larvae of the second brood bore into the pulp of the fruit, causing serious damage; the entrance hole is inconspicuous, but the fruit becomes discoloured and matures too early. The larva pupates in a light web on the ground or between leaves; from the latter most often hymenopterous parasitoids emerge (Fischer von Röslerstamm 1842: 283). A. lineatella is a serious pest on cultivated Prunus in subtropical areas of western Eurasia and North America. In Central Europe the adults fly in two generations a year, from May to July and again during August and September (Kocourek et al. 1996). Further to the south and in the western USA there are 3-4 generations a year (Damos and Savopoulou-Soultani 2008: 467).

Distribution. Widespread in Central and southern Europe and North Africa, eastwards through the Middle East and Turkey to Central Asia and China (Li and Zheng 1997: 122). A. lineatella has been introduced with its host plants to North America where it was present already in the 


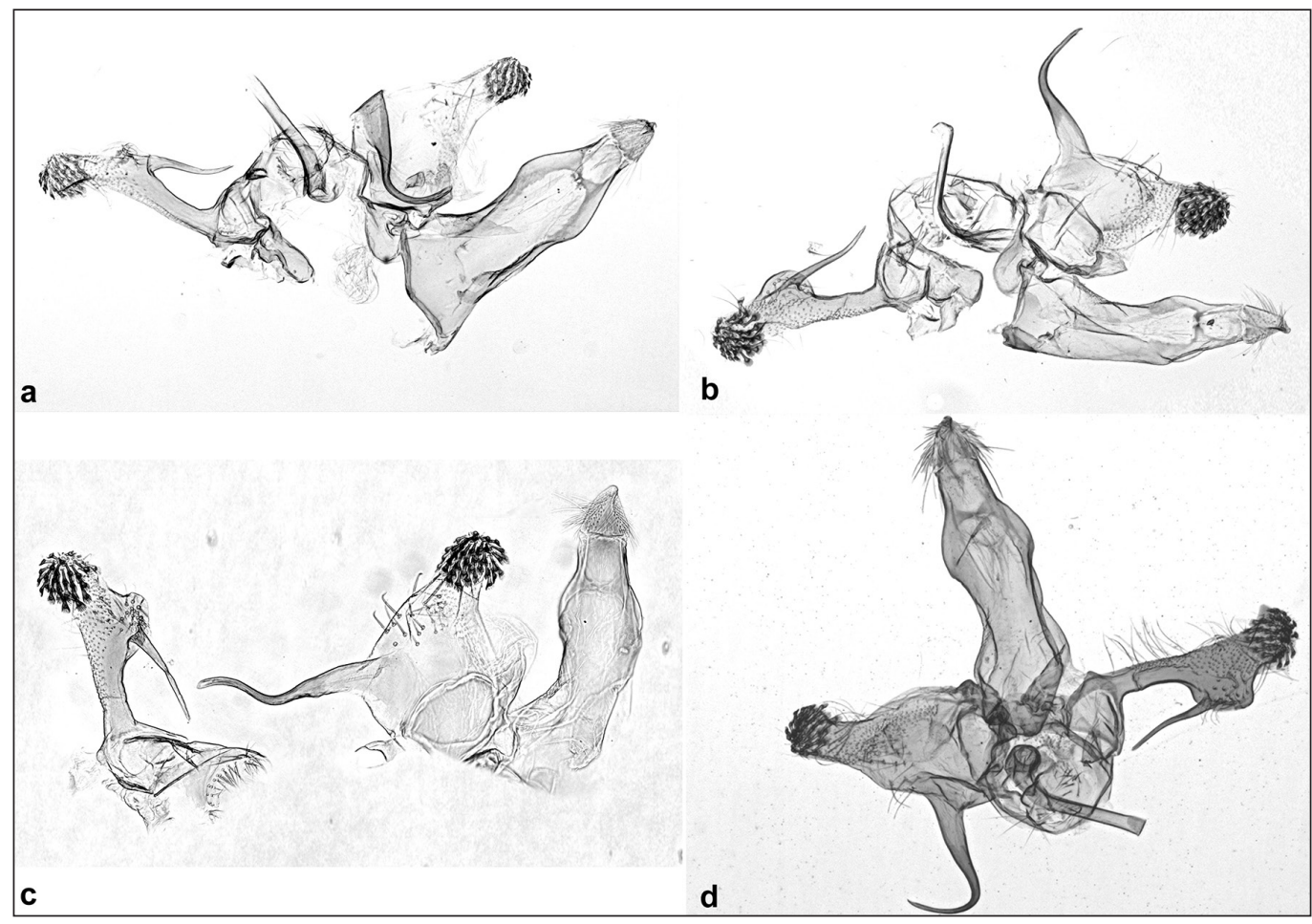

Figure 12. a. Anarsia lineatella, male genitalia, Morocco (KG3365); b. Anarsia lineatella ssp. heratella, male genitalia, holotype (OK5296); c. Anarsia lineatella ssp. tauricella, male genitalia, holotype (OK5300); d. Anarsia lineatella ssp. tauricella, male genitalia, paratype (Amsel 3868).

middle of the 19th century (Clemens 1860). It now occurs all over the USA and southern Canada. Records from other areas need confirmation because of confusion with similar looking species. In Europe the northernmost occurrence seems to be in northern central Germany (Niedersachsen, Nordrhein-Westfalen, and Brandenburg). Records from further north in Europe - and from other parts of the world - are either the result of introductions of fruits or - in most cases - misidentifications of $A$. innoxiella.

Remarks. Anarsia lineatella was described from one male from Austria, Wien, in the collection of Fischer von Röslerstamm ("Lineatella FR"). Whereas the original description by Zeller was very short, Fischer von Röslerstamm (1842: 282-284, pls 95-96) gave a detailed and for that time very good illustrated description of adult, larva, pupa, and life history. It leaves no doubt that he was dealing with the species which is injurious to Prunus spp.

Tinea pullatella was described from an unstated number of specimens from Austria. The type material is probably lost. Hübner's colour painting of pullatella is small, dark, and schematic, and not clearly associated with any species. Hübner (1825: 415) placed pullatella in his genus Gelechia, together with notatella, rhombella, proximella, and mulinella. The first author to deal with pullatella was Treitschke (1833: 95), who gave a re-description which matches A. lineatella. Additionally, he wrote that Geyer (1831: pl. 491) - in the continuation of Hübner's works - figured "eine kleine, haarige, braunschwarze Raupe aus Spartium" (a small, hairy, blackish brown 
larva on broom) (Treitschke 1835: 199, 299). The larva figured by Geyer (who misspelled its name "pulatella") probably belongs to Anarsia spartiella (Schrank, 1802) and is a misidentification as figure 188 in the above mentioned work by Hübner does not fit $A$. spartiella or any other Anarsia species.

Treitschke's interpretation of Tinea pullatella Hübner was not followed by his contemporaries Zeller and Fischer von Röslerstamm, who did not even discuss that species in connection with their description of Anarsia lineatella.

Later Herrich-Schäffer (1855: 153) wrote under Anarsia lineatella: "Pullatella H. 118 stellt diese Art ziemlich kenntlich dar" (Pullatella H.[übner, fig.] 188 depicts this species quite recognizably rather well"). After that time Anarsia pullatella was to our knowledge only used as a valid name by Mann (1861: 190, 1862: 400), who later (e.g., Mann 1866: 355) used A. lineatella for this species.

Tinea pullatella has been out of use for over 150 years (nomen oblitum), and therefore we herewith propose to conserve the name Anarsia lineatella (nomen protectum) and suppress T. pullatella according to the provisions of Article 23.9 (ICZN 1999). Appendix 1 lists 28 references by more than ten different authors that have used $A$. lineatella in the last 50 years.

Anarsia pruniella was described from an unstated number of specimens bred from larvae found $16^{\text {th }}$ June 1860 on Prunus ("plum") at Philadelphia, USA (Clemens 1860: 170).

Anarsia lineatella heratella was described from a series of 9 males and 21 females from Herat in Afghanistan, plus one further female from the Paghman Mts (also in Afghanistan), and two worn specimens from the Muk Pass in Iran. Herat is situated at an altitude of $923 \mathrm{~m}$, but the two other localities are at about $3000 \mathrm{~m}$ altitude, and Amsel (1967: 20) referred the specimens from Iran to his subsp. heratella with some reservation.

We have examined the holotype and three female paratypes from Herat (see Figs $5 \mathrm{~g}, \mathrm{~h}, 12 \mathrm{~b}$ ) and compared them with material from south-east Europe and the Middle East. They look admittedly different from other specimens of Anarsia from that region, but it has not been possible to observe any clear difference in the genitalia between the type material of subsp. heratella and A. lineatella sensu stricto. As we have no sufficient basis for changing the taxonomic status of subsp. heratella we retain it as a subspecies of $A$. lineatella.

In his description of A. lineatella heratella, Amsel (op cit.) refers to figures of its male and female genitalia ("Taf. 7 Fig. 9" and "Taf. 10 Fig. 26"). That reference has been copied into later literature, e.g., Ponomarenko (2009: 341), but the figures are based on German specimens and not of the Afghan subspecies.

Anarsia lineatella tauricella was described from three males and one female from Marasch (now Kahramanmaraş) in Turkey. The country of origin was given as Syria by Amsel (1967: 20), apparently because Marasch was part of Syria when the specimens were collected. We have examined the holotype and two paratypes. The three specimens are similar in external appearance (Fig. 5i, j), with the head and thorax whitish grey, mottled with dark grey, and the ground colour of the forewing light grey overlaid with darker grey. Whereas the genitalia of the allotype are similar to those of other females studied by us, the male genitalia of the two studied specimens (Fig. 12c,d) show some variation. In the holotype the lobe of the left valva is evenly convex (as in typical $A$. lineatella) whilst the paratype has a larger, somewhat rectangular lobe. A similarly shaped lobe is present in Anarsia specimens examined from Israel and south-easternmost Europe examined by us. We find it possible that it represents a further, undescribed species, but due to insufficient material we refrain from describing it here. 
Leraut (1980: 80) listed Lampros (Eupleuris) albilineella Bruand d'Uzelle, 1859 as a synonym of Anarsia lineatella. It is, however, an unnecessary replacement name of Isophrictis lineatellus (Zeller, 1850).

\section{Discussion}

Taxonomy, being the science of naming, describing, and classifying organisms (Secretariat CBD 2008) is both a discipline of its own and an important support to other sciences. It is in itself of value for biodiversity to detect and describe a new species, but a lot of organisms have a more or less direct influence on human health and economy. Among the latter are the so called noxious or pest species, being harmful to crops and other cultivated plants, and numerous people are involved in pest control around the world. It is obvious that efficient pest control depends on a directed effort towards the harmful species. If the taxonomy of the species in question is confused, much effort and money may be wasted trying to control a 'harmless' species.

As mentioned above $A$. innoxiella resembles $A$. lineatella, both externally and in the male and female genitalia, and therefore it has not been possible to separate the two species in the past. However, information on the differences in the host plant preference, and insight into the DNA barcodes, which differ between the two species (P. Huemer and M. Mutanen in litt.), stimulated a more detailed search for morphological differences. By comparing a large sample of moths and genitalia preparations we have discovered diagnostic characters to separate these two species; indeed, with some experience almost all specimens in good condition can be identified by external characters.

The available material of the two taxa A. lineatella subsp. heratella and A. lineatella subsp. tauricella is inadequate to provide a safe basis for a change of their status; however, based on differences in external appearance and the genitalia we are certain that neither of them is conspecific with $A$. innoxiella. Further studies of DNA from fresh material may throw light on the question whether the two subspecies really belong to A. lineatella or represent distinct species. That also applies to specimens with a differently shaped lobe of the left valva, as found in one paratype of A. lineatella tauricella.

\section{Conclusion}

By studying the taxonomy and morphology of the Peach Twig Borer we can demonstrate that Anarsia lineatella shows cryptic diversity and beside the well-known Prunus-feeding pest includes a widespread and common species the larvae of which feed on Acer.

\section{Acknowledgments}

We are particularly grateful to Michael Falkenberg and Robert Trusch (SMNK), David Lees and Klaus Sattler (BMNH), and Andreas Segerer (ZSM) for providing loan and information on type specimens under their care. For donation and loan of material we are indebted to: Leif Aarvik (NHMO); Bjørn Baungaard, Tåstrup, Denmark; Per Falck, Neksø, Denmark; C. Hviid, Virum, Denmark; Urmas Jürivete, Tallinn, Estonia; Benny S. Larsen, Haslev, Denmark; Knud Larsen, Søborg, Denmark; Alex Madsen, Stubbekøbing, Denmark; Danny Nilsson, Kalvehave, Denmark; Eivind Palm, Højer, Denmark; Hartmut Roweck, ECKU; Tomasz Rynarsewski, Poznań, Poland; Nikolay Savenkov, Latvijas Dabas Muzejs, Rīga, Latvia; Rudi Seliger, Nordrhein-Westfalen, 
Germany; Bjarne Skule, Veksø, Denmark; Hartmut Wegner, Nieder Sachsen, Germany; Jacques Wolschrijn, Twello, Netherlands. Marja van Straaten, National Plant Protection Organisation, Wageningen, Netherlands helped with information and literature. Peter Huemer (TLMF) and Marko Mutanen, University of Oulu, Finland generously made data on DNA barcodes of Anarsia species available for this study. Last, but not least, we thank Klaus Sattler, BMNH for linguistic and scientific improvement to the manuscript, an anonymous reviewer, and also Malcolm Scoble, BMNH and the editors Lauri Kaila and Jadranka Rota for additional improvements of the final version of the manuscript. Thomas Pape (ZMUC) gave advice on nomenclatorial matters.

\section{References}

Amsel HG (1959) Microlepidoptera aus Iran. Stuttgarter Beiträge zur Naturkunde 28: 1-47.

Amsel HG (1967) Die afghanischen Arten des Anarsia-Komplexes. Beiträge zur Naturkundlichen Forschung in Südwestdeutschland 26: 17-31.

Amsel HG (1977) Vier neue Kleinschmetterlingsarten aus Iran (Lepidoptera). Beiträge zur Naturkundlichen Forschung in Südwestdeutschland 36: 227-236.

Bae Y-S, Shin Y-M, Na S-M, Park K-T (2016) The genus Anarsia in Cambodia and the Northern Vietnam (Lepidoptera, Gelechiidae), with descriptions of ten new species and a catalogue of the genus in the Central-East Asia. Zootaxa 4061(3): 227-252. https://doi.org/10.11646/zootaxa.4061.3.2

Bruand d'Uzelle CT (1858-59) Classification des Tinéides et examen des caractères et de leur importance relative, d'après la mèthode naturelle. Annales de la Société entomologie de France (1857) (3) 5: 807-826, (1858) (3) 6: 601-702 (1859).

CABI (2016) Datasheet report for Anarsia lineatella (peach twig borer). http://www.cabi.org.ezproxy.library. wur.nl/cpc/datasheetreport?dsid=5154 [visited 30.4.2016]

Clemens B (1860) Contributions to American lepidopterology. 4. Proceedings of the Academy of natural Sciences of Philadelphia 12: 156-174.

Damos P, Savopoulou-Soultani M (2007) Flight patterns of Anarsia lineatella (Lepidopter: Gelechiidae) in relation to degree-days heat accumulation in northern Greece. Communications in applied and biological Sciences 72: 465-468.

Enghoff H, Nielsen ES (1977) Et nyt grundkort til brug for faunistiske undersøgelser i Danmark, baseret på UTM-koordinatsystemet. Entomologiske Meddelelser 45: 65-74.

Geyer C (1831) Larvae Lepidoptera VIII. Tineae V. Ignobiles A. pl. [491]. In: J. Hübner (1793-1842) Geschichte Europäischer Schmetterlinge, $32+16$ pp, 500 pls. Augsburg. http://digital-beta.staatsbibliothek-berlin.de/werkansicht?PPN=PPN66483731X\&PHYSID=PHYS_1045\&DMDID=DMDLOG_0001

Gustavsson B (2017) Svenska fjärilar. http://www2.nrm.se/en/svenska_fjarilar/a/anarsia_lineatella.html [visited 26.1.2017]

Heckford RJ (1992) Anarsia lineatella Zeller (Lepidoptera: Gelechiidae): a larval description. Entomologist's Gazette 43: 54.

Herrich-Schäffer GAW (1847-1855). Systematische Bearbeitung der Schmetterlinge von Europa. 5: 394 pp, $124+7+1$ pls. Regensburg.

Huemer P, Karsholt O (2010) Gelechiidae II (Gelechiinae: Gnorimoschemini). In: Huemer P Karsholt O, Nuss M (Eds) Microlepidoptera of Europe, 6. Apollo Books, Stenstrup, 586 pp.

ICZN (1999) International Code of Zoological Nomenclature, Fourth Edition. International Trust for Zoological Nomenclature, The Natural History Museum London, U.K., 306 pp.

Karsholt O, Riedl T (1996) Gelechiidae, pp 103-113, 118-122, 310-312. In: Karsholt O, Razowski J (Eds) The Lepidoptera of Europe. A distributional checklist. Apollo Books, Stenstrup, 380 pp. 
Kocourek F, Beránková J, Hrdý I (1996) Flight patterns of the peach twig borer, Anarsia lineatella Zell. (Lep., Gelechiidae) in Central Europe as observed using pheromone traps. Anzeiger Schädlingskunde, Pflanzenschutz, Umweltschutz 69: 84-87. https://doi.org/10.1007/BF01908436

Kristensen NP (2003a) Skeleton and muscles: adults 39-131 pp. In: Kristensen NP (Ed.): Lepidoptera: Moths and butterflies 2. Handbuch der Zoologie/Handbook of Zoology IV (36) Walter de Gruyter, Berlin, New York, 427-447.

Kristensen NP (2003b) Reproductive organs. In: Kristensen NP (Ed.) Lepidoptera: Moths and butterflies 2. Handbuch der Zoologie/Handbook of Zoology IV (36), Walter de Gruyter, Berlin, New York, 427-447.

Lepiforum (2016) Anarsia lineatella Zeller, 1839-Pfirsichmotte. http://www.lepiforum.de/lepiwiki.pl?Anarsia_Lineatella [visited 3.11.2016]

Leraut P (1980) Liste Systématique et Synonymique des Lépidoptéres de France, Belgique et Corse. Supplément á Alexanor et Bulletin de la Société entomologie de France. Paris, 334 pp.

Lewis C (2016) British Lepidoptera. http://britishlepidoptera.weebly.com/019-anarsia-lineatella-peachtwig-borer.html [visited 3.11.2016]

Li H, Zheng Z (1998) A taxonomic study on the genus Anarsia Zelller from the mainland of China (Lepidoptera: Gelechiidae). Acta Zoologica Academiae Scientiarum Hungaricae, 43: 121-132.

Mann J (1861) Zur Lepidopteren-Fauna von Amasia. Wiener entomologische Monatschrift 5: 155-162, 183193, pls 2-3.

Mann J (1862) Verzeichniss in Jahre 1851 bei Brussa in Kleinasien gesammelten Schmetterlinge. Wiener entomologische Monatschrift 6: 356-371, 373-409, pl. 3.

Mann J (1866) Aufzählung der im Jahre 1865 in der Dobrudscha gesammelten Schmetterlinge. Verhandlungen der zoologisch-botanischen Gesellschaft in Wien 16: 321-360, pl. 1B.

Piskunov VI (1990) Gelechiidae. In: Medvedev GS (Ed.) Keys to the Insects of the European part of the USSR IV. Leningrad, Lepidoptera 2: 889-1024. [English translation]

Ponomarenko MG (1989) A review of moths of the genus Anarsia Z. (Lepidoptera, Gelechiidae) of the fauna of the USSR. Entomologiceskoe Obozrenie 68: 628-641. [In Russian]

Ponomarenko MG (1992) Functional and morphological analysis of male genitalia of gelechiid moths of the subfamily Dichomeridinae sensu novo (Lepidoptera, Gelechiidae). Entomologiceskoe Obozrenie 71: 160-178. [In Russian]

Ponomarenko MG (1997) Phylogeny and taxonomy of the subfamily Dichomeridinae (Lepidoptera: Gelechiidae). Zoosystematica Rossica 6: 305-314.

Ponomarenko MG (2005) Gelechiid moths (Lepidoptera, Gelechiidae) of the Palaearctics: functional morphology of the male genitalia, phylogeny and taxonomy, Chteniya pamyati N. A. Kholodkovskogo, 58 (1), St.-Petersburg, 139 pp.

Ponomarenko MG (2008) Functional morphology of the male genitalia in Gelechiidae (Lepidoptera) and its significance for phylogenetic analysis. Nota lepidopterologica 31: 179-198.

Ponomarenko MG (2009) Gelechiid moths of the subfamily Dichomeridinae (Lepidoptera: Gelechiidae) of the world. Dal'nauka 2009, Vladivostok, 389 pp.

Treitschke F (1833-35) Die Schmetterlinge von Europa 9(2): 1-294 (1833), 10(3): 1-303 (1835). Leipzig.

Ueda T (1997) A revision of the Japanese species of the genus Anarsia Zeller (Lepidoptera, Gelechiidae). Transactions of the Lepidopterological Society of Japan 48(2): 73-93.

Wolff NL (1965) 1. Anarsia lineatella Zell. (Lep., Gelech.), et nyt dansk skadeinsekt. 2. Laspeyresia leguminana Lien. \& Zeller (Lep., Tort.) fundet i Danmark. Entomologiske Meddelelser 34: 43-53.

Zeller PC (1839) Versuch einer naturgemäßen Eintheilung der Schaben. Isis, Leipzig (1839) 167-220. 


\section{Appendix}

\section{Selected references that have used the name Anarsia lineatella in the last 50 years}

Alston D, Murray M (2007) Peach Twig Borer (Anarsia lineatella). Utah Pest Fact Sheet, ENT-36-07. 1-6. Utah State University Extension and Utah Plant Pest Diagnostic Laboratory, Logan.

Amsel HG (1967) Die afghanischen Arten des Anarsia-Komplexes. Beiträge zur Naturkundlichen Forschung in Südwestdeutschland 26: 17-31.

Baldizzone G., Gozmany L, Huemer P, Karsholt O, Lvovsky A, Parenti U, Passerin d'Entreves P, Riedl T, Varalda PG (1995) Lepidoptera Gelechioidea. Checklist delle specie della fauna Italiana 83: 1-41.

Bradley JD, Fletcher DS (1979) A recorder's log book or label list of British butterflies and moths. Curwen Books, London, [6] $+136 \mathrm{pp}$.

Brunner JF, Rice RE (1984) Peach Twig Borer, Anarsia lineatella Zeller (Lepidoptera: Gelechiidae), Development in Washington and California. Environmental Entomology 13: 607-610.

Buchsbaum U, Löbel H (Eds) (2000) Checkliste der Lepidoptera Thüringens. Check-Listen Thüringer Insekten und Spinnentiere. Thüringer Entomologenverband e. V., Erfurt, 8: 176 pp.

Damos P, Savopoulou-Soultani M (2008) Temperature-Dependent Bionomics and Modeling of Anarsia lineatella (Lepidoptera: Gelechiidae) in the Laboratory. Journal of economic Entomology 101: 1557-1567.

Damos P, Savopoulou-Soultani M (2010) Population dynamics of Anarsia lineatella in relation to crop damage and the development of economic injury levels. Journal of Applied Entomology 134: 105-115.

Emmet AM (Ed.) (1988) A field guide to the smaller British Lepidoptera. Second edition. The British entomological \& natural History Society, London, $288 \mathrm{pp}$

Emmet AM, Langmaid JR (Eds) (2002) Gelechiidae. The Moths and Butterflies of Great Britain and Ireland. Harley Books, Colchester, 4(2): 1-277.

Heckford RJ (1992) Anarsia lineatella Zeller (Lepidoptera: Gelechiidae): a larval description. Entomologist's Gazette 43: 54.

Hodges RW (Ed.) (1983) Check List of the Lepidoptera of America North of Mexico.E.W. Classey Ltd., London \& The Wedge entomological Research Foundation, Washington, i-xxiv $+284 \mathrm{pp}$.

Karsholt O, Riedl T (1996) Gelechiidae, pp 103-113, 118-122, 310-312. In: Karsholt O, Razowski J (Eds): The Lepidoptera of Europe. A distributional checklist. Apollo Books, Stenstrup, 380 pp.

Karsholt O, Mutanen M, Lee S, Kaila L (2013) A molecular analysis of the Gelechiidae (Lepidoptera, Gelechioidea) with an interpretative grouping of its taxa. Systematic Entomology 38: 334-348.

Kocourek F, Beránková J, Hrdý I (1996) Flight patterns of the peach twig borer, Anarsia lineatella Zell. (Lep., Gelechiidae) in Central Europe as observed using pheromone traps. Anzeiger Schädlingskunde, Pflanzenschutz, Umweltschutz 69: 84-87.

Kuchlein JH (1993) De kleine vlinders. Pudoc, Wageningen, 715 pp.

Kuchlein JH, Vos R de (1999) Geannoteerde naamlijst van de Nederlandse vlinders.

Leraut P (1980) Liste Systématique et Synonymique des Lépidoptéres de France, Belgique et Corse. Supplément á Alexanor et Bulletin de la Société entomologie de France. Paris, 334 pp.

Li H, Zheng Z (1998) A taxonomic study on the genus Anarsia Zelller from the mainland of China ((Lepidoptera: Gelechiidae). Acta Zoologica Academiae Scientiarum Hungaricae 43: 121-132.

Park K-T (2013) Arthropoda: Insecta: Lepidoptera: Gelechiidae. Gelechiidae II. Insect Fauna of Korea 16(9). Junghaengsa Inc., Incheon, Korea, 143 pp. 
Piskunov VI (1990) Gelechiidae. In: Medvedev GS (Ed.) Keys to the Insects of the European part of the USSR, IV. Leningrad, Lepidoptera 2: 889-1024. [English translation.

Ponomarenko MG (1989) A review of moths of the genus Anarsia Z. (Lepidoptera, Gelechiidae) of the fauna of the USSR. Entomologiceskoe Obozrenie 68: 628-641 [in Russian].

Ponomarenko MG (2009) Gelechiid moths of the subfamily Dichomeridinae (Lepidoptera: Gelechiidae) of the world. Dal'nauka, 2009, Vladivostok, 389 pp.

Rákosy L, Goia M, Kovács Z (2003) Catalogul Lepidopterelor României. Verzeichnis der Schmetterlinge Rumäniens. Sociatatea Lepidopterologică Romană, Cluj-Napoca, 446 pp.

Réal P (1994) Contribution à la connaissance des Anarsia de France et de pays limitrophes. Mémoires du Comité de Liaison pour les Recherches Ecofaunistiques dan le Jura. Memoire № 12: 1-126.

Sammut PM (1984) A systematic and synonymic list of the Lepidoptera of the Maltese Islands. Neue entomologische Nachrichten 13: 124.

Sattler K (1973) A catalogue of the family-group and genus-group names of the Gelechiidae, Holcopogonidae, Lecithoceridae and Symmocidae (Lepidoptera). Bulletin of the British Museum (natural History), Entomology 28: 153-282.

Sterling P, Parsons M (2012) Field guide to the Micro moths of Great Britain and Ireland. British Wildlife Publishing, Gillingham, 416 pp. 